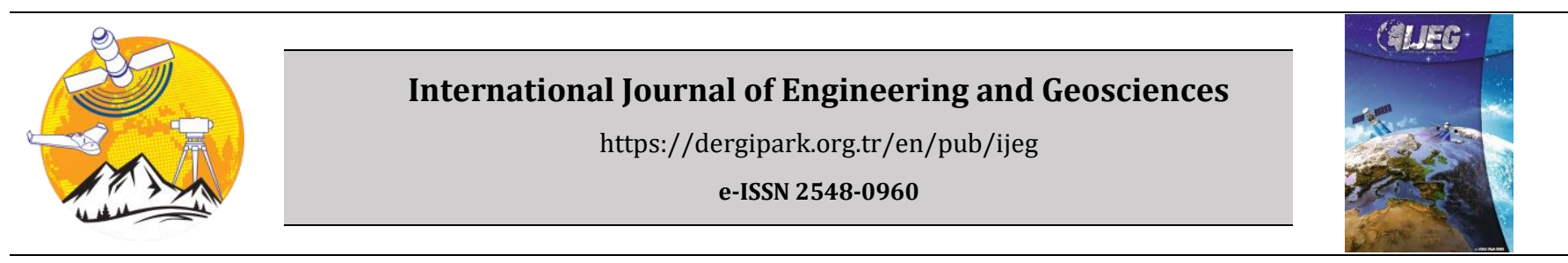

\title{
LiDAR modeling to determine the height of shade canopy tree in cocoa agrosystems as available habitat for wildlife
}

\author{
Baltazar Sanchez-Diaz1 ${ }^{\circledR}$, Ena Edith Mata-Zayas*2®, Lilia Maria Gama-Campillo*2®, Joaquin Alberto Rincon- \\ Ramirez $^{*}{ }^{*}$, Francisca Vidal-Garcia ${ }^{2} \odot$, Cristobal Daniel Rullan-Silva ${ }^{2}{ }^{\oplus}$, Facundo Sanchez-Gutierrez ${ }^{4}$
}

1 Instituto Tecnologico Nacional de Mexico, Instituto Tecnologico Superior de Comalcalco, Comalcalco, Tabasco, Mexico 2Universidad Juarez Autonoma de Tabasco, Division Academica de Ciencias Biologicas, Villahermosa, Tabasco, Mexico ${ }^{3}$ Colegio de Postgraduados, Campus Tabasco, Cardenas, Tabasco, Mexico

${ }^{4}$ Universidad Autónoma de Chiapas, Facultad Maya de Estudios Agropecuarios, Palenque, Chiapas, Mexico

\author{
Keywords \\ Conservation \\ Canopy Height \\ Humid Tropics \\ Point Cloud \\ Model
}

\begin{abstract}
Agrosystems have different canopy strata due to shade trees that serve as available habitats for endangered species such as birds, reptiles, and mammals. LiDAR is a technology used to assess habitat quality as a support for designing conservation strategies. The objective of this research was to develop a model with data derived from LiDAR to obtain the height of the shade canopy in cocoa agrosystems, as a habitat available for wildlife species. Through the data of the height of the vegetation taken in the field and the data obtained from a LiDAR point cloud, the Canopy Height Model was generated. The data from the mapping of the canopy height model of the agrosystems taken as study sites were validated using the coefficient of determination $\left(\mathrm{R}^{2}\right)$, mean absolute error (MAE), and the RMSE. The mean canopy height at the study sites was $14.63,13.84$, and $13.95 \mathrm{~m}$, and the results of the validation using the model predicted canopy height shows good agreement with the actual value with an $\mathrm{R}^{2}$ of 0.86 , and very low values of MAE $=1.88$, MSE $=5.64$, and RMSE $=2.37$, which indicates that they have an acceptable degree regarding the canopy height model between the LiDAR data and the data taken in the field. Research using LiDAR provides useful information to determine the height of the canopy, in the cocoa agrosystems up to 3 strata are found, this is due to the diversity of tree species used as shade, ranging from timber, fruit, ornamental, which are used as feeding, nesting, and resting of wildlife, in the study area populations of howler monkey species that are listed as endangered by the International Union for Conservation of Nature (IUCN), in addition to other species such as bats and birds, with the presence of these species indicate that the cocoa agrosystems, serve as a habitat for a diversity of species, which is why it is important to conserve these agrosystems in the humid tropics.
\end{abstract}

\section{INTRODUCTION}

Tropical forests support a large proportion of plant and animal species, many of them are threatened or endangered by the increased deforestation and change in land use caused by human activities (Cottontail et al., 2009; Raghubanshi and Tripathi, 2009). Therefore, some wildlife species in the Mexican humid tropics such as bats (Oporto et al., 2015) and the endangered tree mammal Alouatta palliata (Sanchez-Gutiérrez et al., 2016a) have sought refuge in shade-grown agrosystems, such as cocoa and coffee plantations. These agrosystems are important for maintaining vertebrate diversity in tropical landscapes modified by humans since they can provide temporary or permanent habitat, function as stopover sites, increase tree cover and the availability of potential resources, for isolated wildlife populations (Rice and Greenberg, 2000; Estrada and Coetes-Estrada, 2002; Daily et al., 2003; Harvey et al., 2004). Besides, these agrosystems favor carbon sequestration, water 
capture, soil conservation, and other ecosystem services (García-Mayoral et al., 2015; Alexander et al., 2018a). Trees that provide shade have different canopy height strata and a great diversity of species (Somarriba et al., 2004; Salgado-Mora et al., 2007; Villavicencio-Enriquez, 2013). Therefore, shade-grown agrosystems such as cocoa and coffee play an important role as available habitats due to their complex structure and high diversity, becoming important spaces in conservation strategies in mega-diverse countries such as Mexico, Brazil, Colombia, India, Indonesia, and Malaysia (Bisseleua et al., 2009).

Forest vertical stratification can be classified into four levels: emerging layer, canopy, undergrowth, and soil layer (Pelt and Franklin, 2000; Minton, 2003), while the vertical stratification of cocoa agrosystems has been classified as high, medium, low, and floor (Somarriba $e t$ al., 2004). The knowledge of the different layers of the shade canopy, as well as the diversity that constitutes it, helps to understand the value that agrosystems have as a habitat. This information in turn allows agrosystems to be included in conservation strategies for threatened species (Alexander et al., 2018b). Different studies have shown the importance of forest agrosystems as a habitat for the survival of species. For example, at the local level in the municipality taken as a case study in this project, it has been reported that the richness of birdlife in the cacao groves is associated with the structure of the vegetation and its diversity of trees (Ibarra et al., 2001). In coffee agrosystems in India, the presence of wild species such as palm civet Paradoxurus hermaphroditus and the jungle palm squirrel Funambulus tristriatus has been reported (Caudill et al., 2014). In Mexico, in coffee agrosystems of the State of Chiapas, species such as naked-eared deer mouse Peromyscus gymnotis, yaguarundi or eyra wild cat Puma yagouaroundi, and white-nosed coati Nasua narica (Cassano et al., 2014) have been observed. In cocoa agrosystems like the ones in Brazil, species in danger of extinction have been found according to the International Union for the Conservation of Nature (IUCN), such as the goldenheaded lion marmoset Leontopithecus chrysomelas, the Brazilian rabbit Sylvilagus brasiliensis, and the yellowbreasted capuchin Sapajus xanthosternos (Cassano et al., 2014). In Mexico, in the state of Tabasco, the mantled howler monkey Alouatta palliata mexicana has been studied in cocoa agrosystems (Valenzuela-Córdova et al., 2015; Sanchez-Díaz et al., 2019), in addition to a great diversity of birds (Ibarra et al., 2001).

In Mexico, most cocoa production takes place in the humid tropic, mainly in the states of Tabasco and Chiapas, and to a lesser extent in Oaxaca, Veracruz and Guerrero (Espinosa-Garcia et al., 2015). In the cocoa agrosystems in Tabasco, the most common tree species are: guácimo (Guazuma ulmifolia), ceiba (Ceiba pentandra), moté or colorín (Erythrina americana) and saman (Samanea saman) (Muñoz et al., 2006; Valenzuela-Córdova et al., 2015; Sanchez-Díaz et al., 2019; Sanchez-Gutiérrez et al., 2016b). These tree species are very tall and with a large canopy diameter, therefore, it is important to estimate dendrometry variables derived from the vertical structure of these agrosystems.
Conventional methods for estimating quantitative forest variables are based on field measurements and are generally limited in terms of spatial and temporal sampling (Funes et al., 2017). On the other hand, remote sensing provides methods to generate information on the vegetation structure, characterization, monitoring, and mapping of changes in land coverage at local, regional and global scales (Funes et al., 2017; Giri, 2012). LiDAR is an airborne or terrestrial remote sensing technology, which uses light as laser points to measure the distance between the sensor and a target surface and enables three-dimensional information to be generated about the shape of the earth and its surface characteristics (Bombi et al., 2019). This allows obtaining a point cloud to calculate Digital Surface Models (DSM), Digital Terrain Models (DTM), and Canopy Height Models (CHM). The CHM model is obtained by subtracting the DTM from the DSM (Park et al., 2015; Marcu et al., 2017), and threedimensional information is generated on the characteristics of different classes of land coverage and vegetation structure (Parent et al., 2015). This type of technology has been used to estimate quantitative forest variables such as canopy height, coverage, and structure, to describe the vertical structure of forests in studies on biodiversity conservation (Lefsky et al., 2002).

LiDAR technology has been used for different studies, for example, in Brazil to detect coconut plantations (Cocos nucifera) (Mohan et al., 2019a), in Spain to estimate the vertical canopy structure of wild pine (Pinus sylvestris) (Fidalgo-González et al., 2019), in Indonesia and Malaysia to characterize the vertical structure of tropical rainforests, using a canopy height model (Alexander et al., 2018a; Wassihun, 2019), and in Mexico to estimate dendrometry attributes and variables such as canopy height, basal area and crown diameter in forests (Ortiz-Reyes et al., 2015). In the United Kingdom, they have used LiDAR technology to estimate habitat suitability in planning conservation areas for the red squirrel Sciurus vulgaris an endangered species (Flaherty et al., 2014). This technology has been recommended for studies on habitat structure (Bombi et al., 2019), as canopy height is an important attribute for evaluating the quality of habitat and for modeling ecological niches for birds, reptiles, and trees mammals (Lesak et al., 2011).

The objective of this study was to develop a model based on vegetation height data taken in the field and data obtained from a LiDAR point cloud to determine the canopy height and strata of shade trees in cocoa agrosystems as available habitats for the wildlife.

\section{METHOD}

To develop the canopy height model, the following stages were considered: 1) field measurement of dendrometry variables (normal diameter, canopy coverage and height), 2) generation of digital models of terrain, surface and vegetation height from LiDAR data, 3) adjustment of canopy height model using regression analysis, considering the data obtained in the field with the LiDAR data, 4) validation of canopy height predicted by the model with data observed in the field, 5) statistical analysis and evaluation of the Adjusted Model of canopy height, 6) correlation between the height of the trees and 
the presence of wildlife. Finally, the cartographic representation of the canopy height model was generated (Figure 1).

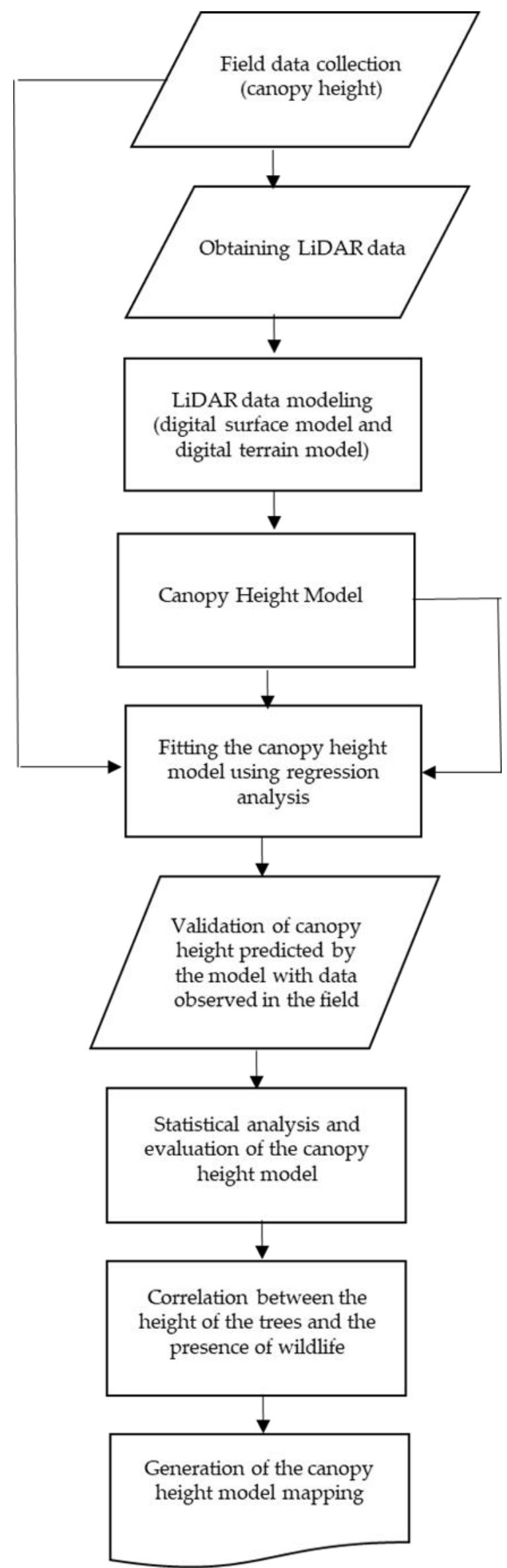

\subsection{Study Area}

The study was carried out in three cocoa agrosystems, located in the municipality of Comalcalco, Tabasco, Mexico (Figure 2). The sites were selected from previous studies where it has been documented they are used as wildlife habitat (Table 1), particularly for howler monkeys A. palliata. At each site, 10 plots of $10 \times 25 \mathrm{~m}$ were established (Rugnitz et al., 2009), for a total of 26 temporary sampling plots (TMP).
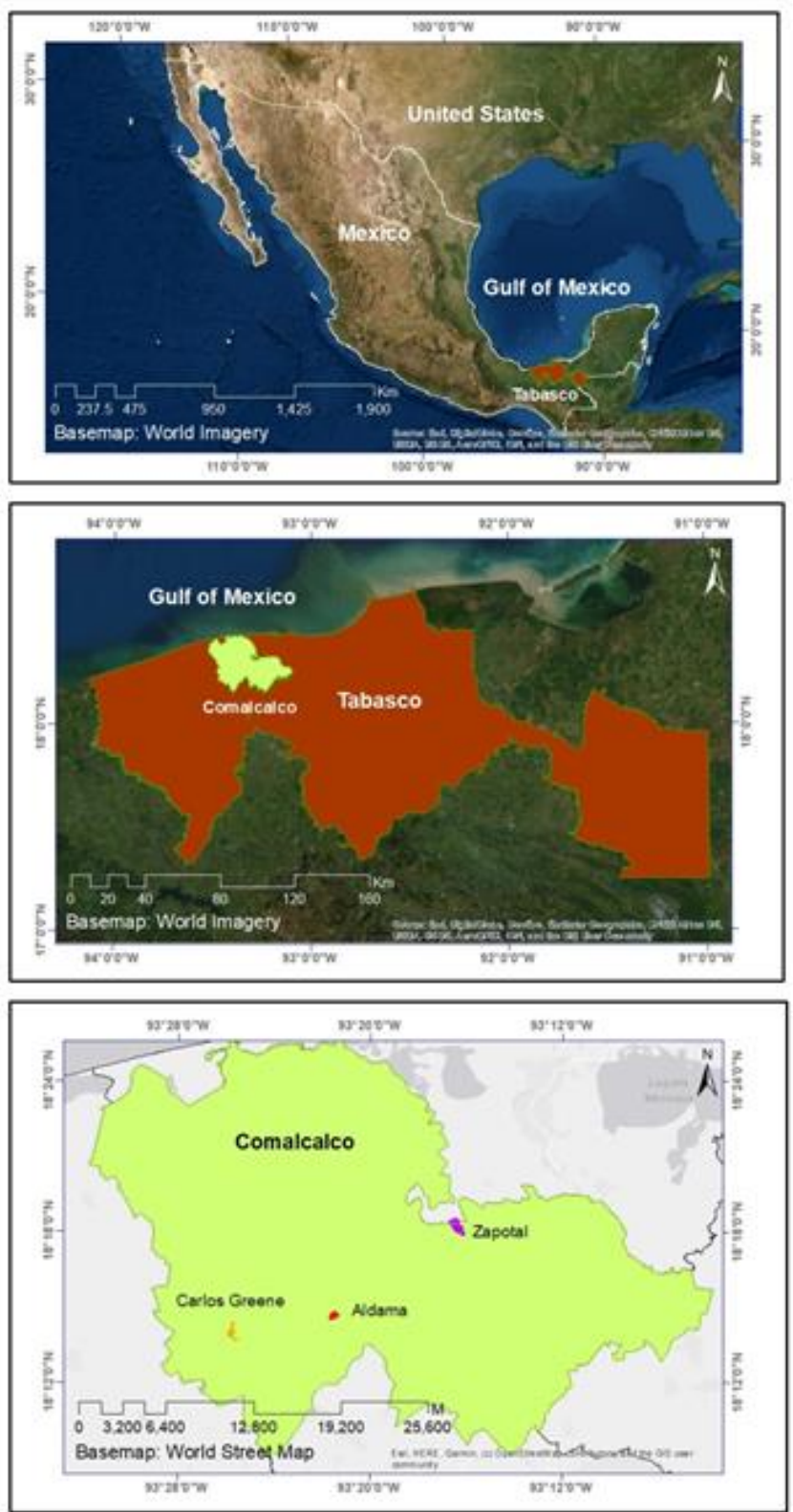

Figure 2. Location of cocoa agrosystems used as study sites at the Municipality of Comalcalco, state of Tabasco, Mexico.

\subsection{Collection of Field Data}

In each temporal sampling plot (TMP), dendrometry variables on the field of all trees were measured: canopy cover and height (Figure 3, Table 2).

Figure 1. Flowchart each step of the study plan 
Table 1. Cocoa agrosystems sites are used to generate canopy height models

\begin{tabular}{llllll}
\hline Site & Location & Latitude & Length & Surface & Source \\
\hline SA1 & Carlos Greene & $18^{\circ} 13^{\prime} 59.20^{\prime \prime} \mathrm{N}$ & $93^{\circ} 25^{\prime} 52.19^{\prime \prime} \mathrm{W}$ & 49.59 ha & (Valenzuela, 2018) \\
SA2 & Aldama & $18^{\circ} 14^{\prime} 37.56^{\prime \prime} \mathrm{N}$ & $93^{\circ} 21^{\prime} 39.81^{\prime \prime} \mathrm{W}$ & 21.08 ha & (Sanchez-Díaz et al. 2019) \\
SA3 & Zapotal & $18^{\circ} 17^{\prime} 58.98^{\prime \prime} \mathrm{N}$ & $93^{\circ} 16^{\prime} 22.00^{\prime \prime} \mathrm{W}$ & 57.82 ha & (Vidal-García and Serio-Silva, 2011) \\
\hline
\end{tabular}

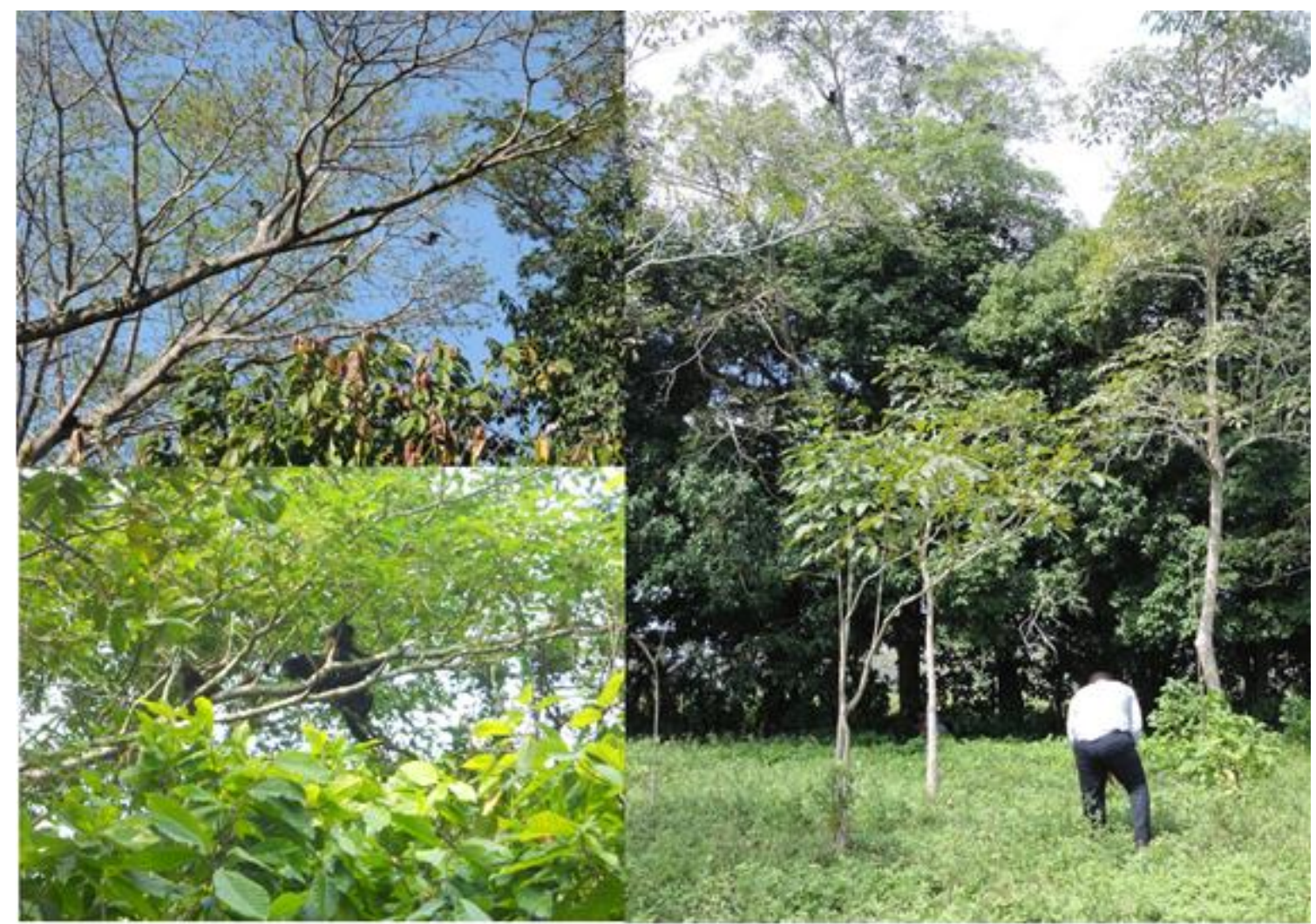

Figure 3. Collection and measured of field data

Table 2. Dendrometry variables

\begin{tabular}{|c|c|c|}
\hline Variable & Measurement Description & Equation \\
\hline Canopy Height & $\begin{array}{l}\text { The angles of the tree base }(\theta) \text {, the canopy }(\rho) \text { and the horizontal distance } \\
\text { (hd) were measured using a clinometer. }\end{array}$ & $\mathrm{Ht}=\mathrm{hd}(\tan \rho+\tan \theta)$ \\
\hline Canopy cover & $\begin{array}{l}\text { The projection was measured in two directions on the ground, North - South } \\
\text { and East - West }\end{array}$ & $\mathrm{Dc}=(\mathrm{dc} 1+\mathrm{dc} 2) / 2$ \\
\hline
\end{tabular}

\subsection{Obtaining and Modeling LiDAR Data}

The aerial LiDAR point cloud used was provided by INEGI of an overflight carried out in 2012, with a point density on the ground, for one swath, was of 0.47 points $/ \mathrm{m}^{2}$ for the first return, 0.20 points $/ \mathrm{m}^{2}$ for the second return, 0.02 points $/ \mathrm{m}^{2}$ for the third return, and 0.0001 points $/ \mathrm{m}^{2}$ for the fourth return. To process the LiDAR point cloud, an analysis was performed with the tool Insights and the LASTools module through the ArcGIS v9.2 software. Once this information was processed, the Digital Terrain (DTM) and Surface (DSM) Models were generated. Subsequently, the Model of Canopy Height (CHM) was developed, which was obtained by subtracting the DTM from the DSM (Park et al., 2015; Marcu et al., 2017; Mohan et al., 2019b). A Canopy Height Model (CHM) was generated for each site.

\subsection{Model Adjustment to Estimate Vegetation height}

Because the LiDAR data is from 2012, the CHM was updated. To obtain the updated canopy height, the CHM was fitted with a regression model (Martin-Garcia et al., 2017; Zuazo et al., 2017). For this, the height data were taken in the field (dependent variable Y) was related to the height data derived from LiDAR (independent variable $\mathrm{X}$ ). To analyze the goodness of the adjusted model, the coefficient of determination statistic (R2) was used.

\subsection{Statistical Analysis and Validation of the Canopy Height Model (CHM)}

The statistical parameters of the Canopy Height Model were calculated in the three cocoa agrosystems, these statistics were: minimum and maximum height, a mean and standard deviation of the canopy height. The canopy height predicted by the model was validated with data observed in the field, so a sample size was calculated with a reliability level of $90 \%(\mathrm{z}=1.645)$ and a confidence interval of 10\% (Aguilar-Barojas, 2005). Three statistical measures were used to assess model performance: the coefficient of determination (R2), mean absolute error (MAE), and the RMSE. 


\subsection{Analysis of the correlation between the height of the trees and the presence of wildlife}

To detect whether the presence of primates such as Alouatta palliata and height were related, a correlation and regression analysis was performed. This made it possible to identify if there was any association between them. The analysis was performed using SAS software.

\subsection{Mapping Generation}

With the information obtained from LiDAR data, the Canopy Height Model mapping was generated. The classification proposed by Somarriba et al. (2004) was adopted to determine the canopy height of cocoa agrosystems: floor, low, medium and high. Likewise, a topographic profile was developed for each study site, where, along a transect, the evolution of altimetry is shown. The mapping was developed in ArcGIS v9.2 software.

\section{RESULTS}

\subsection{Mapping Generation}

Models generated from the LiDAR point cloud are shown below (Figure 4). The Digital Terrain Model (DTM) shows the three-dimensional representation of the terrain surface. The Digital Surface Model (DSM) shows the representation of the elevations above sea level of the reflective surfaces of trees on the ground.

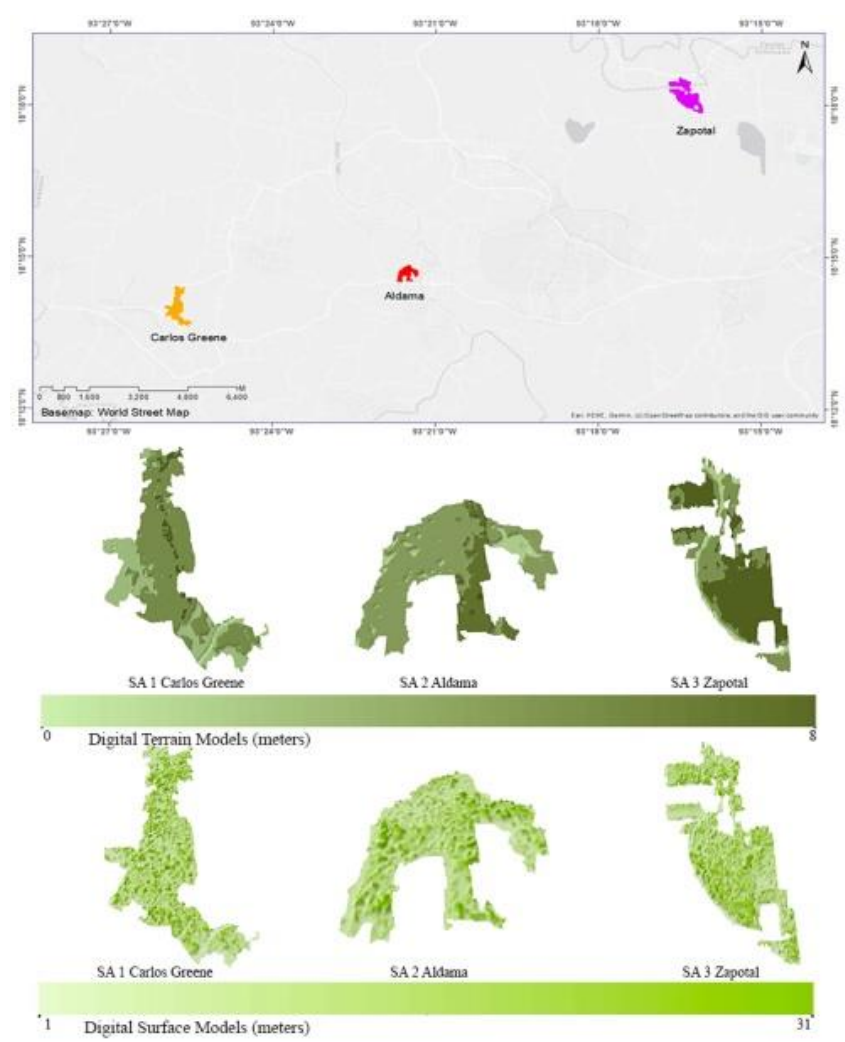

Figure 4. Digital Terrain Model (above) and Digital Surface Model (below) in three cocoa agrosystems in Tabasco, Mexico

\subsection{Regression Analysis}

The scatter diagram indicates that height data resulting from LiDAR (independent variable $\mathrm{X}$ ) are strongly correlated with the height data taken in the field (dependent variable Y), where, there is a slope of 1.27 and an offset of $-0.53 \mathrm{~m}$; the value of the coefficient of determination R2 was 0.991, therefore, there are no observed trends of overestimation or underestimation (Figure 5).

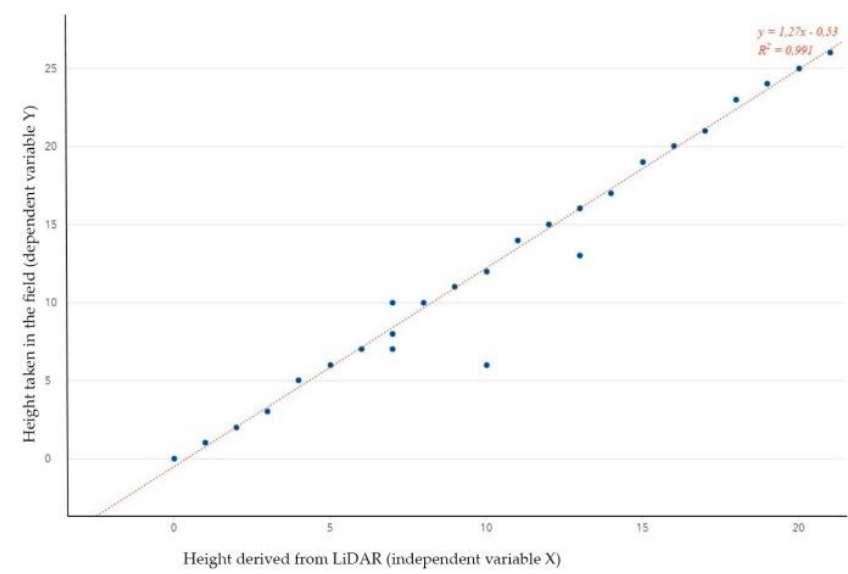

Figure 5. Scatterplot representing the fit of the independent variable (X) and the dependent variable (Y)

\subsection{Statistical Analyzes of the Canopy Height Model}

The site with the highest mean height canopy was SA 1 with 14.63 , while the lowest value was SA2 with 13.84 $\mathrm{m}$ (Table 3). The range of canopy heights varied from 10 to $33 \mathrm{~m}$.

Table 3. Mean height Canopy in cocoa agrosystems

\begin{tabular}{llll}
\hline LiDAR Variables & SA 1 & SA 2 & SA 3 \\
\hline Maximum height (m) & 33 & 32 & 26 \\
Minimum height (m) & 10 & 10 & 10 \\
Mean (m) & 14.63 & 13.84 & 13.95 \\
Standard deviation (m) & 4.16 & 3.79 & 3.11 \\
\hline
\end{tabular}

The model predicted canopy height shows good agreement with the observed values in the field with an R2 of 0.86 . Analytically, MAE, MSE and RMSE have very low values (Table 4). This suggests that the developed model provides good performance results for the mapping of the canopy height in cocoa agrosystems.

Table 4. The values of validation measures between predicted and observed data

\begin{tabular}{llll}
\hline MAE & MSE & RMSE & R $^{2}$ \\
\hline $1.88(\mathrm{~m})$ & $5.64(\mathrm{~m})$ & $2.37(\mathrm{~m})$ & $0.86(\mathrm{~m})$ \\
\hline
\end{tabular}

\subsection{Correlation between the height of the trees and the presence of wildlife}

Pearson's correlation showed a high correlation of 0.95 between the height where the presence of wildlife species was recorded and the total height of the tree (Table 5). The height of the canopy predicted by the model shows a good agreement with the height where 
the wildlife species were observed with an R2 of 0.91 . Analytically, MAE, MSE and RMSE have very low values (Figure 6).

Table 5. Correlation between the presence of wildlife and the height of the trees

\begin{tabular}{lcc}
\hline \multicolumn{3}{c}{ Pearson correlation coefficient, $\mathrm{N}=24$} \\
Prob $>|\mathrm{r}|$ suppose H0: Rho=0 \\
\hline & PRESENCE_WILDLIFE & TREE_HEIGHT \\
PRESENCE_WILDLIFE & 1.00000 & 0.95620 \\
TREE_HEIGHT & 0.95620 & $<.0001$ \\
& $<.0001$ & 1.00000 \\
\hline
\end{tabular}

\subsection{Mapping}

Vertical stratification of these agrosystems is classified as high, medium, low and floor (Somarriba et al., 2004). Shade trees in cocoa agrosystems used as study sites are found in the upper-middle strata (Figure 7).

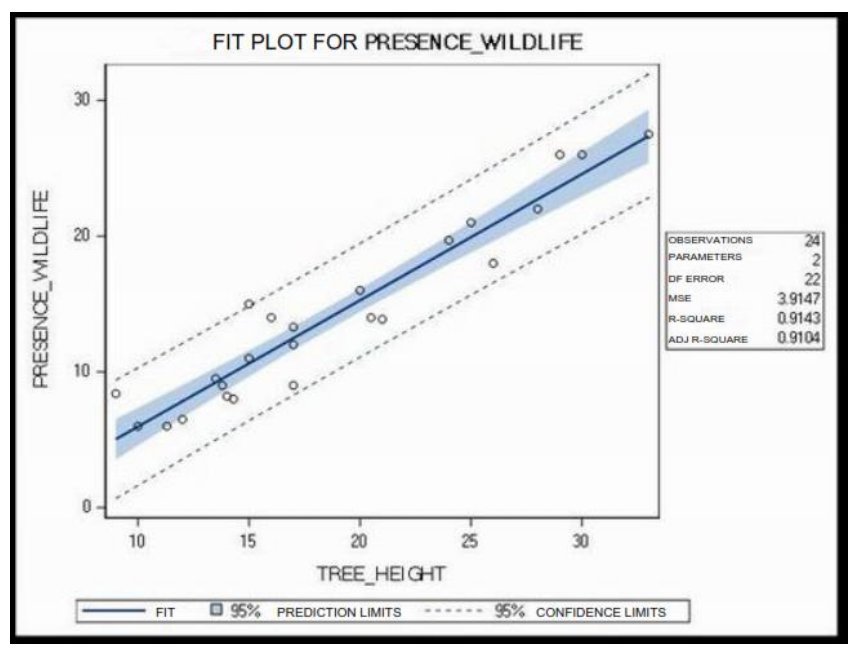

Figure 6. Regression of wildlife presence and tree height
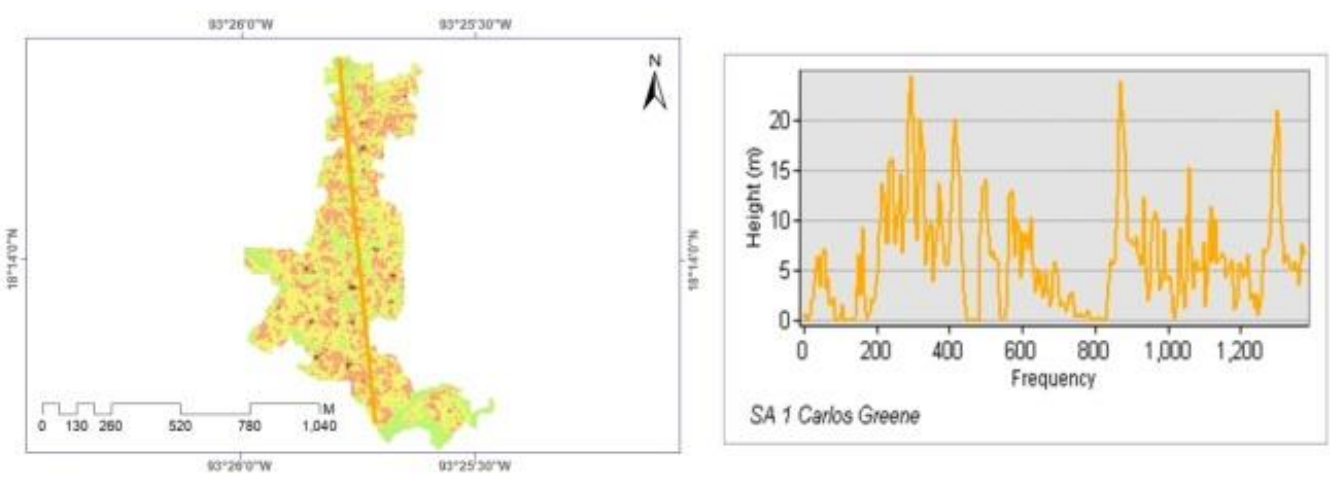

SA 1 Carlos Greene
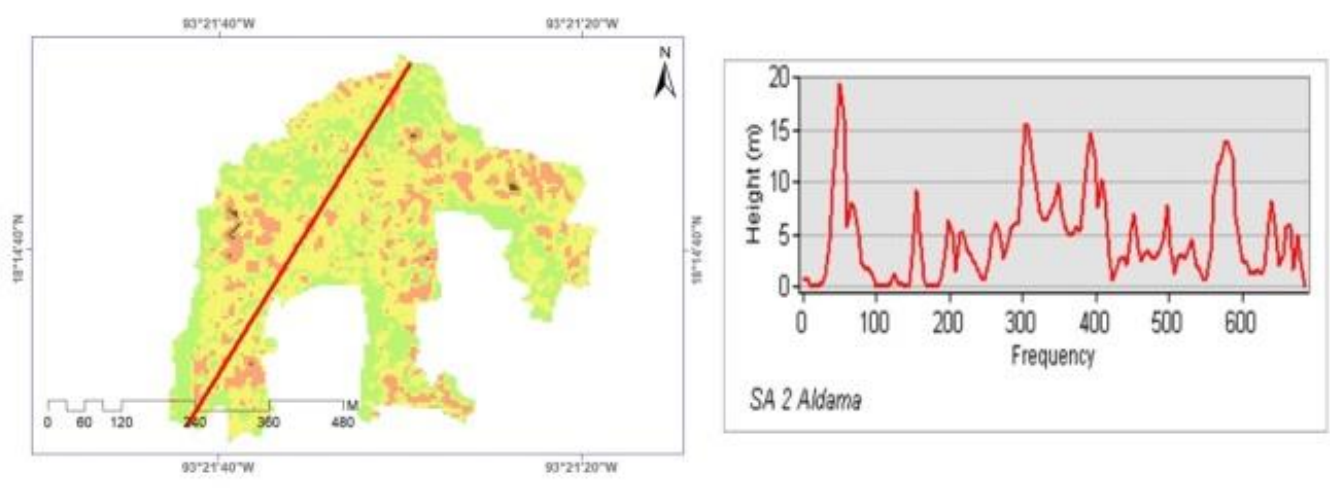

SA 2 Aldama
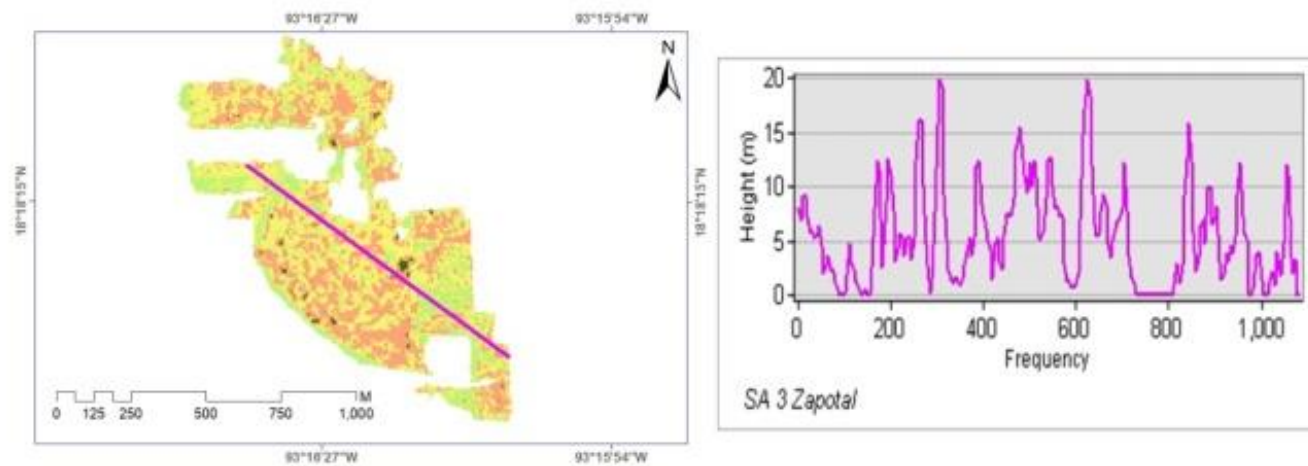

SA 3 Zapotal

Vegetation Height Values (meters)

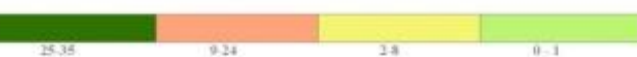

Figure 7. Canopy Height Model (CHM) and elevation profile for cocoa agrosystems 


\section{DISCUSSION}

The loss of tropical forest cover generated by human activities has caused some wildlife species to seek refuge in agroforestry systems, such as cocoa and coffee (Cicuzza et al., 2011; Zarate et al., 2014). Although these systems do not replace the ecological complexity of forests, vertical stratification, as well as dominance, density and frequency of tree species is important since it favours the conservation of species in wildlife (Salgado-Mora et al., 2007). In the case of cocoa plantations in Tabasco, some reports indicate howler monkeys living there and using the native vegetation as a source of food (Valenzuela, 2018). Most of the activity of howlers is developed in the shadow vegetation because outside of the agrosystems there is not available vegetation. Both the vertical stratification and the diversity of trees present, favour their use as places of refuge, nesting and feeding among others, having the potential to provide habitats for wildlife. Some examples of species that use agrosystems are Leontopithecus chrysomelas, Sylvilagus brasiliensis, Sapajus xanthosternos and Alouatta palliata mexicana, considered as endangered according to IUCN (Bhagwat et al., 2008; McDermott et al., 2015).

In agrosystems of other countries such as Cameroon, Colombia and Brazil, it has been observed that species with higher height are Mangifera indica and Spondias mombin (Sambuichi et al., 2012; Mbolo et al., 2016; Salazar et al., 2018). Also, fruit trees such as Citrus sinensis, Annona muricata and Persea americana (Asase et al., 2010; Mbolo et al., 2016), and timber species such as Tabebuia rosaea, Tabebuia guayacan, were found at study sites, and Swietenia macrophylla (vulnerable species, IUCN 1998). All these tree species are used as shade trees in cocoa plantations and are important for native fauna, as they represent a source of food and shelter for endangered species. For example, in Colombia, the lazy bear (Bradypus variegatus) uses plant species such as Spondias mombin and Bursera simarouba (Ballesteros et al., 2009) in its diet, and the white-headed marmoset (Saguinus oedipus) uses Tabebuia rosea and Cedrela odorata leaves as food (De la ossa et al., 2014). In Costa Rica, the jabirú (Jabiru mycteria) uses Ceiba pentandra trees as a habitat to place their nests over 25 $\mathrm{m}$ high (Orias, 2009). In Mexico, in the municipality of Balancan, Tabasco, elements of Mangifera indica and Tabebuia rosea were recorded in the Alouatta pigra diet (Aristizabal-Borja, 2013); in Comalcalco, Tabasco howler monkeys were identified feeding on species like Spondias mombin, Mangifera indica, Bursera simaruba and Erythrina americana (Muñoz et al., 2005). These tree species are part of the structure and diversity of the species used as shade, which serve as food for wildlife because they offer food throughout the year according to the seasonal production of the different plant parts, they can consume new leaves (sprouts), fruits and flowers (Aristizabal-Borja, 2013). They also provide shelter between their branches with abundant leaves, which allow temperature regulation, aid in the digestion process and, at the same time, as a refuge for protection from predators (De la ossa et al., 2014). Therefore, diversification in agrosystems, through the rational incorporation of shade trees, to increase the overall production of the system, can be a strategy that allows producers to compensate for economic losses caused by price fluctuations and low production of coffee and cocoa (Alline et al., 2016); thus, promote shade trees in cocoa plantations as a way of preserving wildlife species (Cicuzza et al., 2011), such as insects, birds and mammals (Mbolo et al., 2016; Asase et al., 2010).

The canopy height models in cocoa agrosystems were generated from the LiDAR point cloud of INEGI (2012), with a resolution of 0.47 points $/ \mathrm{m}^{2}$. However, to obtain better information such as the canopy diameter and identify tree species resulting from LiDAR data, it is recommended to work with a cloud of density points higher than 0.5 points $/ \mathrm{m}^{2}$ (Gonzalez-Ferreiro et al., 2013; Bujan et al., 2013). LiDAR technology has been used in studies of different plantations with a resolution higher than the one recommended. In a Cocos nucifera crop in Brazil, canopy cover was estimated with a resolution of 3 points $/ \mathrm{m}^{2}$ (Mohan et al., 2019a). In the United States, it has been used for the delimitation of individual deciduous trees, with a resolution of 2.3 points $/ \mathrm{m}^{2}$ (Shao et al., 2019). In Indonesia, the cover and height of the mangrove canopy were mapped, with a resolution of 4 points $/ \mathrm{m}^{2}$ (Mahadi et al., 2018). In Malaysia, a model was developed to delineate individual trees in a tropical forest, with a resolution of 8.8 points $/ \mathrm{m}^{2}$ (Wan-Mohd et al., 2017). In Spain, the canopy has been outlined in Pinus radiata Don, with a resolution of 0.5 points $/ \mathrm{m}^{2}$ (Gonzalez-Ferreiro et al., 2017). In Mexico, in the state of Hidalgo, a forest inventory was generated in a temperate forest, through a private LiDAR flight with a density of 5 points $/ \mathrm{m}^{2}$ (Ortiz-Reyes et al., 2015).

The updated shade canopy height model was adjusted with a regression model between the canopy height obtained in the field and the aerial LiDAR point cloud (Martinez-Tobon et al., 2013; Cabrera et al., 2014; Martin-Garcia et al., 2017; Zuazo et al. 2017). Calculation of coefficient of determination (R2), mean absolute error (MAE), and the RMSE, showed good performance results of the adjusted Model prediction. This allows reducing the costs of a LiDAR flight and space sampling when it is sought to update the canopy height of the shade trees in cocoa agrosystems. However, there are other models built using neural networks, a branch of Artificial Intelligence, which has obtained good results to classify the LiDAR point cloud over the air and to evaluate metrics derived from LiDAR technology with variables from different sensors (Funes et al., 2017; Zhao et al., 2019).

A statistical estimate of shade canopy height generated the mean and standard deviation values at the three study sites $13.84 \pm 3.79,14.63 \pm 4.16$ and $13.95 \pm$ 3.11 respectively. This is important since the preferential use of the strata where habitats preferably used by species such as Alouatta palliata and Lagothrix poeppigii are found and canopies between 15-20 m have been reported (Pozo, 2009; Arcos et al., 2013). Data obtained in the analysis through LiDAR were validated in the field, using the coefficient of determination (R2), mean absolute error (MAE), and the RMSE, showing that the vegetation height values were good when adjusting the 
canopy height model between the LiDAR data and the data taken in the field, thus confirming the validity. LiDAR technology has also been used to estimate habitat suitability, to support the planning of conservation areas for threatened species (Flaherty et al., 2014). The use of remote sensors, both in natural vegetation and in agrosystems has evidenced the importance of knowing the vertical structural complexity of vegetation and terrain in general, and not only horizontal heterogeneity (Zamora-Martinez, 2017). The use of data derived from LiDAR technology to analyze habitat structure will help to strengthen the implementation of actions to contribute to biodiversity conservation (Bombi et al., 2019; Zamora-Martinez, 2017). For example, the preferred tree height for Loris tardigradus is between 6$14 \mathrm{~m}$ (Gamage et al., 2009), while Trachypithecus pileatus spends most of its time between the canopy height of 5 $15 \mathrm{~m}$, and Hoolock hoolock spends time between 6-20 m (Islam et al., 2014).

\section{CONCLUSION}

The use of data derived from LiDAR technology provided reliable information to generate the canopy height model. The application of the regression model with the data taken in the field allowed generating the cartography of the height of the canopy of the shade trees in the cocoa agrosystems, through LiDAR the analysis of the height can be facilitated in agroforestry plantations that can be used as available wildlife habitat. It is recommended that for future studies, a spatial resolution higher than 0.47 points per square meter be used; this resolution will allow extracting information such as the diameter of the canopy and identify tree species, important attributes in the habitat structure for the species. The canopy height of shade trees is an important attribute, since they are used as food, nesting and resting of wildlife, in particular for birds, bats and tree primates, and thus, supports decision-makers to generate conservation strategies.

\section{ACKNOWLEDMENT}

Authors thank the National Council of Science and Technology of Mexico (CONACYT), for granting the scholarship for the research work, and the National Institute of Statistics and Geography (INEGI) for providing the LiDAR data used in this research.

\section{Author contributions}

Baltazar Sanchez Diaz: Methodology, Visualization, Editing; Ena Edith Mata Zayas: Methodology, WritingOriginal draft preparation, Editing; Lilia Maria Gama Campillo: Conceptualization, Investigation, WritingReviewing; Joaquin Alberto Rincon Ramirez: Statistical analysis Writing-Original draft preparation; Francisca Vidal Garcia: Visualization, Investigation, Writing-Reviewing and Editing; Cristobal Daniel Rullan Silva: Data curation, Visualization, Statistical analysis, Writing-Reviewing and Editing; Facundo Sanchez Gutierrez: Conceptualization, Investigation, WritingReviewing.

\section{Conflicts of interest}

The authors declare no conflicts of interest.

\section{REFERENCES}

Aguilar-Barojas S (2005). Fórmulas para el cálculo de la muestra en investigaciones de salud. Salud en Tabasco, 11(1-2), 333-338.

Alexander C, Korstjens A H, Usher G, Nowak M G, Fredriksson G \& Hill R A (2018a). LiDAR patch metrics for object-based clustering of forest types in a tropical rainforest. International Journal of Applied Earth Observation and Geoinformation, 73, 253-261.

Alexander C, Korstjens A H \& Hill R A (2018b). Influence of micro-topography and crown characteristics on tree height estimations in tropical forests based on LiDAR canopy height models. International journal of applied earth observation and geoinformation, 65, 105-113.

Allinne C, Savary S \& Avelino J (2016). Delicate balance between pest and disease injuries, yield performance, and other ecosystem services in the complex coffeebased systems of Costa Rica. Agriculture, Ecosystems \& Environment, 222, 1-12.

Asase A, Ofori-Frimpong K \& Ekpe P K (2010). Impact of cocoa farming on vegetation in an agricultural landscape in Ghana. African Journal of Ecology, 48(2), 338-346.

Arcos R, Ruiz A, Altamirano M \& Albuja Viteri L H (2013). Uso del estrato vertical por el mono aullador (Alouatta palliata) (Primates: Atelidae) en un bosque subtropical del Noroccidente de Ecuador.

Aristizábal-Borja J (2013). Estrategias de forrajeo y características nutricionales de la dieta del mono aullador negro (Alouatta pigra) en un ambiente fragmentado. Xalapa, Veracruz: MSc dissertation, Instituto de Ecología, A. C.

Ballesteros J, Reyes K \& Racero J (2009). Estructura poblacional y etología de Bradypus variegatus en fragmento de bosque seco tropical, CórdobaColombia. Revista MVZ Córdoba, 14(3), 1812-1819.

Bisseleua D H B, Missoup A D \& Vidal S (2009). Biodiversity conservation, ecosystem functioning, and economic incentives under cocoa agroforestry intensification. Conservation biology, 23(5), 11761184.

Bombi P, Gnetti V, D’Andrea E, De Cinti B, Taglianti A V, Bologna M A \& Matteucci G (2019). Identifying priority sites for insect conservation in forest ecosystems at high resolution: the potential of LiDAR data. Journal of Insect Conservation, 1-10.

Bhagwat S A, Willis K J, Birks H J B \& Whittaker R J (2008). Agroforestry: a refuge for tropical biodiversity. Trends in ecology \& evolution, 23(5), 261-267.

Buján S, González-Ferreiro E, Barreiro-Fernández L, Santé I, Corbelle E \& Miranda D (2013). Classification of rural landscapes from low-density lidar data: is it theoretically possible? International journal of remote sensing, 34(16), 5666-5689.

Cabrera J, Lamelas M T, Montealegre A L \& Riva J D L (2014). Estimación de variables dasométricas a partir 
de datos LiDAR PNOA en masas regulares de Pinus halepensis Mill.

Caudill S A, Vaast P \& Husband T P (2014). Assessment of small mammal diversity in coffee agroforestry in the Western Ghats, India. Agroforestry systems, 88(1), 173-186.

Cassano C R, Barlow J \& Pardini R (2014). Forest loss or management intensification? Identifying causes of mammal decline in cacao agroforests. Biological Conservation, 169, 14-22.

Cottontail V M, Wellinghausen N \& Kalko E K V (2009). Habitat fragmentation and haemoparasites in the common fruit bat, Artibeus jamaicensis (Phyllostomidae) in a tropical lowland forest in Panamá. Parasitology, 136(10), 1133-1145.

Cicuzza D, Kessler M, Clough Y, Pitopang R, Leitner D \& Tjitrosoedirdjo S S (2011). Conservation value of cacao agroforestry systems for terrestrial herbaceous species in central Sulawesi, Indonesia. Biotropica, 43(6), 755-762.

Daily G C, Ceballos G, Pacheco J, Suzán G \& SánchezAzofeifa A (2003). Countryside biogeography of neotropical mammals: conservation opportunities in agricultural landscapes of Costa Rica. Conservation biology, 17(6), 1814-1826.

De La Ossa J \& Lacayo A D L O (2014). Densidad poblacional de Saguinus oedipus (Primates Callitrichidae) y disponibilidad de alimento vegetal, Colosó, Sucre-Colombia. Revista UDCA Actualidad \& Divulgación Científica, 17(2).

Estrada A \& Coates-Estrada R (2002). Bats in continuous forest, forest fragments and in an agricultural mosaic habitat-island at Los Tuxtlas, Mexico. Biological Conservation, 103(2), 237-245.

Espinosa-García J A, Uresti-Gil J, Vélez-Izquierdo A, Moctezuma-López G, Inurreta-Aguirre H D \& Góngora-González S F (2015). Productividad y rentabilidad potencial del cacao (Theobroma cacao L.) en el trópico mexicano. Revista mexicana de ciencias agrícolas, 6(5), 1051-1063.

Flaherty S S, Lurz P W \& Patenaude G (2014). Use of LiDAR in the conservation management of the endangered red squirrel (Sciurus vulgaris L.). Journal of Applied Remote Sensing, 8(1), 083592.

Fidalgo-González L, Arellano-Pérez S, Álvarez-González J G, Castedo-Dorado F, Ruiz-González A D \& GonzálezFerreiro E (2019). Estimación de la distribución vertical de combustibles finos del dosel de copas en masas de Pinus sylvestris empleando datos LiDAR de baja densidad. Revista de Teledetección, (53), 1-16.

Funes P A, Camacho C J N, Calcerrada R R, Jiménez, R V, Bernal R N R \& Rojas W R (2017). Evaluación de la correlación entre variables métricas derivadas de tecnología LiDAR y variables del sensor MISR, mediante modelos de regresión con redes neuronales. XXV congreso de la AGE 50 años de congresos de geografía, naturaleza, territorio y ciudad en un mundo global, Madrid, España.

García Mayoral L E, Valdez Hernández J I, Luna Cavazos M \& López Morgado R (2015). Estructura y diversidad arbórea en sistemas agroforestales de café en la Sierra de Atoyac, Veracruz. Madera y bosques, 21(3), 69-82.
Gamage S, Liyanage W K D D, Weerakoon D \& Gunwardena A (2009). Habitat quality and availability of the Sri Lanka red slender Loris Loris tardigradus tardigradus (Mammalia: Primates: Lorisidae) in the Kottawa Arboretum. Journal of Threatened Taxa, 1(2), 65-71.

Giri C P (2012). Brief overview of remote. Remote sensing of land use and land cover: principles and applications, 1 .

González-Ferreiro E, Diéguez-Aranda U, BarreiroFernández L, Buján S, Barbosa M, Suárez J C, Bye J \& Miranda D (2013). A mixed pixel-and region-based approach for using airborne laser scanning data for individual tree crown delineation in Pinus radiata D. Don plantations. International journal of remote sensing, 34(21), 7671-7690.

González-Ferreiro E, Arellano-Pérez S, Castedo-Dorado F, Hevia A, Vega J A, Vega-Nieva D, Álvarez-González J G \& Ruiz-González A D (2017). Modelling the vertical distribution of canopy fuel load using national forest inventory and low-density airbone laser scanning data. PloS one, 12(4), e0176114.

Harvey C A, Tucker N I \& Estrada A (2004). Live fences, isolated trees, and windbreaks: tools for conserving biodiversity in fragmented tropical landscapes. Agroforestry and biodiversity conservation in tropical landscapes. Island Press, Washington, DC, 261-289.

Ibarra A C, Arriaga S \& Estrada A (2001). Avifauna asociada a dos cacaotales tradicionales en la región de la Chontalpa, Tabasco, México. Universidad y Ciencia, 34(17).

Islam M, Choudhury P \& Bhattacharjee P C (2014). Canopy utilization pattern of Western Hoolock Gibbon Hoolock Hoolock (Mammalia: Primates: Hylobatidae) in the Inner-line Reserve Forest of Barak Valley, Assam, India. Journal of Threatened Taxa, 6(9), 6222-6229.

IUCN (1998). Guidelines for Re-introductions. Prepared by the IUCN/SSC Reintroductions Specialist Group - IUCN, Gland, Switzerland and Cambridge, UK.

Lesak A A, Radeloff V C, Hawbaker T J, Pidgeon A M, Gobakken T \& Contrucci K (2011). Modeling forest songbird species richness using LiDAR-derived measures of forest structure. Remote Sensing of Environment, 115(11), 2823-2835.

Lefsky M A, Cohen W B, Parker G G \& Harding D J (2002). Lidar remote sensing for ecosystem studies: Lidar, an emerging remote sensing technology that directly measures the three-dimensional distribution of plant canopies, can accurately estimate vegetation structural attributes and should be of particular interest to forest, landscape, and global ecologists. BioScience, 52(1), 19-30.

Mbolo M M A, Zekeng J C, Mala W A, Fobane J L, Chimi C D, Ngavounsia T, Nyako C M, Menyene L F E \& Tamanjong Y V (2016). The role of cocoa agroforestry systems in conserving forest tree diversity in the Central region of Cameroon. Agroforestry systems, 90(4), 577-590.

Martín-García S, Diéguez-Aranda U, Álvarez González J G, Pérez-Cruzado C, Buján S \& González-Ferreiro E (2017). Estimación de las existencias maderables de 
Pinus radiata a escala provincial utilizando datos LiDAR de baja resolución. Bosque (Valdivia), 38(1), 17-28.

Marcu C, Stătescu F \& Iurist N (2017). A GIS-Based Algorithm to Generate a Lidar Pit-Free Canopy Height Model. Present Environment and Sustainable Development, 11(2), 89-95.

Martínez Tobón C D, Aunta Duarte J E \& Valero Fandiño J A (2013). Aplicación de datos LiDAR en la estimación del volumen forestal en el parque metropolitano bosque San Carlos. Ciencia E Ingeniería Neogranadina, 23(1), 7-21.

Mahadi A T \& Siregar V P (2018). Mapping of mangrove coverage and canopy height using LiDAR data at Sangkulirang District, East Kutai, East Borneo. In IOP Conference Series: Earth and Environmental Science (Vol. 176, No. 1, p. 012026). IOP Publishing.

McDermott M E, Rodewald A D \& Matthews S N (2015). Managing tropical agroforestry for conservation of flocking migratory birds. Agroforestry Systems, 89(3), 383-396.

Minton S (2003). Using movement to teach academics: An outline for success. Journal of physical education, recreation \& dance, 74(2), 36-40.

Mohan M, de Mendonça B A F, Silva C A, Monte M A, de Saboya Ribeiro A S, de Araújo E J G \& Cardil A (2019a). Optimizing individual tree detection accuracy and measuring forest uniformity in coconut (Cocos nucifera L.) plantations using airborne laser scanning. Ecological Modelling, 409, 108736.

Mohan M, Catts G P, Vaughan B, Roise J P, Silva C A, McCarter J B, Jat P, Gopan G \& Maulud K A (2019b). What Makes a Location into a "Favorable Habitat" under Changing Climate and Environmental Conditions? A Pilot Study Focused on Exploring the Differences between Natural and Non-natural Habitats using Airborne LiDAR. Earth and Environmental Science, 228 (1), 012018.

Muñoz D, Estrada A, Naranjo E \& Ochoa S (2006). Foraging ecology of howler monkeys in a cacao (Theobroma cacao) plantation in Comalcalco, Mexico. American Journal of Primatology, 68(2), 127-142.

Muñoz D, Estrada A \& Naranjo E (2005). Monos aulladores (Alouatta palliata) en una plantación de cacao (Theobroma cacao) en Tabasco, México: aspectos de la ecología alimentaria. Universidad y Ciencia, (II), 35-44.

Orias J V (2009). El jabirú (Jabiru mycteria) en Costa Rica: población y conservación. Biocenosis, 22(1-2).

Ortiz-Reyes A D, Valdez-Lazalde J R, los Santos-Posadas D, Héctor M, Ángeles-Pérez G, Paz-Pellat F \& Martínez-Trinidad T (2015). Inventario y cartografía de variables del bosque con datos derivados de LiDAR: comparación de métodos. Madera y bosques, 21(3), 111-128.

Oporto S, Arriaga-Weiss S L \& Castro-Luna A A (2015). Diversidad y composición de murciélagos frugívoros en bosques secundarios de Tabasco, México. Revista mexicana de biodiversidad, 86(2), 431-439.

Parent J R, Volin J C \& Civco D L (2015). A fully-automated approach to land cover mapping with airborne LiDAR and high-resolution multispectral imagery in a forested suburban landscape. ISPRS Journal of Photogrammetry and Remote Sensing, 104, 18-29.

Park W Y, Sohn H G \& Heo J (2015). Estimation of forest canopy height using orthoimage-refined digital elevation models. Landscape and ecological engineering, 11(1), 73-86.

Pelt R V \& Franklin J F (2000). Influence of canopy structure on the understory environment in tall, oldgrowth, conifer forests. Canadian Journal of Forest Research, 30(8), 1231-1245.P

Pozo W E (2009). Uso preferencial de hábitat en primates atélidos en el Parque Nacional Yasuní, Ecuador. Boletín Técnico, Serie Zoológica, 8(4-5).

Raghubanshi A S \& Tripathi A (2009). Effect of disturbance, habitat fragmentation and alien invasive plants on floral diversity in dry tropical forests of Vindhyan highland: a review. Tropical Ecology, 50(1), 57.

Rice R A \& Greenberg R (2000). Cacao cultivation and the conservation of biological diversity. AMBIO: A Journal of the Human Environment, 29(3), 167-174.

Rugnitz M, Chacón M \& Porro R (2009). Guia para Determinação de Carbono em Pequenas Propriedades Rurais. Centro Mundial Agroflorestal (ICRAF) Consórcio Iniciativa Amazônica (IA). Belém, Brasil, $81 \mathrm{p}$.

Salgado-Mora M G, Ibarra-Núñez G, Macías-Sámano J E \& López-Báez O (2007). Diversidad arbórea en cacaotales del Soconusco, Chiapas, México. Interciencia, 32(11), 763-768.

Sánchez-Gutiérrez F, Pérez-Flores J, Obrador Olan J J, Sol Sánchez Á, \& Ruiz-Rosado O (2016a). Estructura arbórea del sistema agroforestal cacao en Cárdenas, Tabasco, México. Revista mexicana de ciencias agrícolas, 7(SPE14), 2695-2709.

Sánchez-Gutiérrez F, Pérez-Flores J, Obrador Olan J J, Sol Sánchez Á \& Ruiz-Rosado O (2016b). Estructura arbórea del sistema agroforestal cacao en Cárdenas, Tabasco, México. Revista Mexicana de Ciencias Agrícolas, (14).

Sánchez-Díaz B, Mata-Zayas E, Gama L, Rullan-Silva C, Vidal-García F \& Rincón-Ramírez J (2019). Use of different spectral vegetation indices to determine the presence of mantled howler monkeys (Alouatta palliata G.) on cocoa agrosystems (Theobroma cacao L.). Applied ecology and environmental research, 17(1), 1279-1297.

Sambuichi R H, Vidal D B, Piasentin F B, Jardim J G, Viana T G, Menezes A A, Mello D L N, Ahnert D \& Baligar V C (2012). Cabruca agroforests in southern Bahia, Brazil: tree component, management practices and tree species conservation. Biodiversity and Conservation, 21(4), 1055-1077.

Salazar J C S, Bieng M A N, Melgarejo L M, Di Rienzo J A \& Casanoves F (2018). First typology of cacao (Theobroma cacao L.) systems in Colombian Amazonia, based on tree species richness, canopy structure and light availability. PloS one, 13(2), e0191003.

Shao G, Shao G \& Fei S (2019). Delineation of individual deciduous trees in plantations with low-density LiDAR data. International journal of remote sensing, 40(1), 346-363. 
Somarriba E, Domınguez L \& Harvey C (2004). ¿Cómo evaluar y mejorar el dosel de sombra en cacaotales. Agroforestería en las Américas, 41(42), 120-128.

Valenzuela-Córdova B, Mata-Zayas E E, PachecoFigueroa C J, Chávez-Gordillo E J, Díaz-López H M, Gama L \& Valdez-Leal J D D (2015). Potencial ecoturístico del agrosistema cacao (Theobroma cacao L.) con monos saraguatos (Alouatta palliata Gray) en la Chontalpa, Tabasco. Agroproductividad, 8(5).

Valenzuela C B (2018). Evaluación del hábitat disponible para monos saraguatos (Alouatta palliata mexicana) en el agrosistema de cacao en el municipio de Comalcalco, Tabasco, México. Universidad Juárez Autónoma de Tabasco.

Vidal-García F \& Serio-Silva J C (2011). Potential distribution of Mexican primates: modeling the ecological niche with the maximum entropy algorithm. Primates, 52(3), 261.

Villavicencio-Enríquez L (2013). Caracterización agroforestal en sistemas de café tradicional y rústico, en San Miguel, Veracruz, México. Revista Chapingo. Serie ciencias forestales y del ambiente, 19(1), 67-80.

Wassihun A N (2019). Sensitivity of Above-Ground Biomass to Terrestrial LIDAR-Derived Tree Height in Berkelah Tropical Rainforest, Malaysia. Journal of the Indian Society of Remote Sensing, 47(5), 789-799.
Wan-Mohd-Jaafar W S, Woodhouse I H, Silva C A, Omar H \& Hudak A T (2017). Modelling individual tree aboveground biomass using discrete return lidar in lowland dipterocarp forest of Malaysia. Journal of Tropical Forest Science, 465-484.

Zárate D A, Andresen E, Estrada A \& Serio-silva J C (2014). Black howler monkey (Alouatta pigra) activity, foraging and seed dispersal patterns in shaded cocoa plantations versus rainforest in southern Mexico. American Journal of Primatology, 76(9), 890-899.

Zhao C, Yu D, Xu J, Zhang B \& Li D (2019, August). Airborne LiDAR point cloud classification based on transfer learning. In Eleventh International Conference on Digital Image Processing (ICDIP 2019) (Vol. 11179, p. 1117920). International Society for Optics and Photonics.

Zamora-Martínez M C (2017). La tecnología LiDAR, herramienta útil para el estudio de la biodiversidad. Revista mexicana de ciencias forestales, 8(39), 4-6.

Zuazo I L, Gracia A L M \& Gracia M T L (2017). Cartografía de la biomasa aérea total en masas de Pinus radiata D. don a partir de datos públicos Lidar-PNOA e inventario forestal nacional. GeoFocus. Revista Internacional de Ciencia y Tecnología de la Información Geográfica, (20), 87-107. 